"Relationship between the application of IFRS and the accounting information quality in Jordan"

\begin{tabular}{|c|c|}
\hline AUTHORS & Qasim Ahmad Alawaqleh (D https://orcid.org/0000-0001-6964-4785 \\
\hline ARTICLE INFO & $\begin{array}{l}\text { Qasim Ahmad Alawaqleh (2020). Relationship between the application of IFRS } \\
\text { and the accounting information quality in Jordan. Investment Management and } \\
\text { Financial Innovations, 17(4),111-120. doi:10.21511/imfi.17(4).2020.11 }\end{array}$ \\
\hline DOI & http://dx.doi.org/10.21511/imfi.17(4).2020.11 \\
\hline RELEASED ON & Tuesday, 24 November 2020 \\
\hline RECEIVED ON & Saturday, 19 September 2020 \\
\hline \multirow[t]{2}{*}{ ACCEPTED ON } & Monday, 02 November 2020 \\
\hline & $((c))_{E Y}$ \\
\hline LICENSE & $\begin{array}{l}\text { This work is licensed under a Creative Commons Attribution } 4.0 \text { International } \\
\text { License }\end{array}$ \\
\hline JOURNAL & "Investment Management and Financial Innovations" \\
\hline ISSN PRINT & $1810-4967$ \\
\hline ISSN ONLINE & $1812-9358$ \\
\hline PUBLISHER & LLC "Consulting Publishing Company "Business Perspectives" \\
\hline FOUNDER & LLC "Consulting Publishing Company "Business Perspectives" \\
\hline & 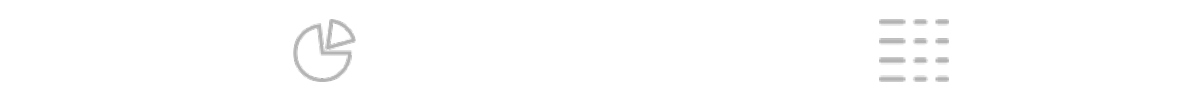 \\
\hline NUMBER OF REFERENCES & NUMBER OF FIGURES \\
\hline 36 & 5 \\
\hline
\end{tabular}

(C) The author(s) 2021. This publication is an open access article. 


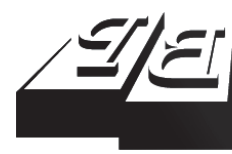

BUSINESS PERSPECTIVES

(O)

LLC "CPC "Business Perspectives" Hryhorii Skovoroda lane, 10, Sumy, 40022, Ukraine www.businessperspectives.org
Received on: $19^{\text {th }}$ of September, 2020 Accepted on: $2^{\text {nd }}$ of November, 2020 Published on: $24^{\text {th }}$ of November, 2020

(c) Qasim Ahmad Alawaqleh, 2020

Qasim Ahmad Alawaqleh, Associate Professor of Accounting, Accounting Department, Philadelphia University, Jordan.

\section{RELATIONSHIP BETWEEN THE APPLICATION OF IFRS AND THE ACCOUNTING INFORMATION QUALITY IN JORDAN}

\begin{abstract}
The study aimed to find out the relationship between the application of international financial reporting standards (IFRS) and the accounting information quality (AIQ) in Jordan. The research data was collected from 59 industrial companies listed on the Amman Stock Exchange (ASE) between 2010 and 2018. Panel data was used to measure an independent variable (the application of IFRS), and a questionnaire (a 5-point Likert scale) was applied to measure a dependent variable (AIQ). Multiple regression was used to test hypotheses. The study concluded that the application of IFRS in terms of earnings management and trading volume had a positive relationship with AIQ. Finally, the study recommended validating the transparency of financial reporting to improve the efficiency of the Jordanian financial market.
\end{abstract}

Keywords IFRS, AIQ, ASE, Jordan

JEL Classification M41

\section{INTRODUCTION}

The study of the impact of IFRS application on AIQ is a topical issue in order to find out the results of the application, both positive and negative, on the Jordanian capital market, and then the impact on economic growth in Jordan. The research gap is that most of the previous studies focused on developed capital markets, but the ASE did not receive the same attention. Some studies have shown that the importance of accounting information in developed countries may differ from that in least developed countries due to the different economic, social and cultural characteristics between developed and developing countries (Graham et al., 2000, pp. 84-107, Richards, 1996, p. 461). In fact, accounting theory did not directly address the role of accounting information in emerging markets. The success of capital markets depends directly on the quality of the accounting system and financial disclosure that investors trust (Levitt, 1998, pp. 79-83). On the other hand, maintaining high quality of accounting information requires strict compliance with the laws and publications that govern the accounting profession, without the use and control of some accounting standards that give management an estimate of certain elements of financial reporting (Huoshu \& Chen, 2014). Thus, the increasing importance of accounting information requires more than simply applying high-quality accounting standards, whether local or international, which requires effective mechanisms to ensure that companies are committed to the proper application of accounting standards (Hellstrom, 2006, pp. 325-344). In line with that, Barth et al. (2005) concluded that IFRS improve the prediction and quality of accounting information; however, lax application of these standards undermines 
their effectiveness in producing high-quality information. Kothari (2000) agrees with the above, as he argues that the quality of accounting information is affected not only by the quality of accounting standards, but also by the nature of corporate governance and the legal system. However, the variability of information may be more significant on the ASE compared to developed markets, because the sources of information are fewer; this makes accounting information more important to ASE participants than in more developed markets (Lopes, 2002).

\section{LITERATURE REVIEW}

IFRS is the main gateway to the globalization of accounting; therefore, various countries around the world strive to apply these standards in a compulsory or optional manner. Despite the importance of financial reports prepared in accordance with accounting standards, the obligation to implement them varies from country to country depending on the accounting organization and the legal legislation governing the accounting profession in each country. As such, the effects of the application of IFRS on the quality of accounting information and investment decisions differ from country to country. In this context, some believe that the application of IFRS produces the desired results only in countries with strong capital markets that enhance accountability and transparency and ensure the commitment to implementing these standards (David, 2013). In 2005, Leake gave a lecture at the Institute of Chartered Accountants in England and Wales (ICAEW) on the advantages and disadvantages that investors could experience as a result of implementing IFRS. He warned of the implications of applying these standards because they will not be clear in the short term and will differ from one country to another depending on the extent of commitment to their application. Hence, many studies showed different accounting issues due to different implications of applying or adopting these standards (Stojilkovic 2011, pp. 91-109, Goodwin \& Heaney, 2008, pp. 89-119). Not only that, while many studies have focused on different accounting issues and different effects of applying or adopting these standards, more recently most research has emphasized the benefits of implementing IFRS, such as increased transparency, reduced capital costs, and improved investments across countries (Barth et al., 2008, pp. 467:498). On the other hand, some studies have raised questions about whether some of the benefits are from early application of IFRS or from simultaneous improvements to these reports (Ramanna \& Sletten, 2014, pp. 1517-
1543). Recent studies have focused on the effects of IFRS on reducing inconsistencies in accounting numbers (Louis \& Urcan, 2014). Besides that, other studies have reviewed IFRS-related research; for example, Soderstrom and Sun (2007, pp. 675702) examined the optional application of international accounting standards and their association with accepted accounting principles in the United States of America. Further, Hail et al. (2010, pp. 355-394) examined the potential effects of US companies' transition to IFRS on quality of accounting information, cost, and capital markets, while Pope and McLeay (2011, pp. 233-266) focused on the implementation of IFRS in European Union countries and how to use these standards to improve disclosure and transparency.

One of the stated goals of adopting IFRS is to improve the quality of reports and improve the comparison of financial statements across countries (Hsu \& Pourjalai, 2014). According to the European Parliament, the adoption of international financial reporting standards by listed companies will lead to a high degree of transparency and comparability of financial statements and capital market efficiency.

\section{METHODOLOGY}

\subsection{The accounting measurement and hypotheses}

Previous studies used relevance and reliability to measure the quality of accounting information. Cheung et al. (2010) showed that the relevance of accounting information quality is vital for making a decision. Also, Beest et al. (2009) asserted that the applying fair value is appropriate for assessing the relevance of the accounting information quality. In relation to that, reliability is a crucial feature of the accounting information quality. The researcher emphasizes that the accounting infor- 
mation quality should be reliable to be active, and this can be achieved if the financial statements do not contain material distortions and bias. The users of accounting information depend on reliability through unbiased accounting information (Cheung et al., 2010; Beest et al., 2009; Willekens, 2008; Downen, 2014).

In relation to that, the dependent variable (accounting information quality) is a continuous variable, and a 5-point Likert Scale is used to measure it. On the other hand, this study depended on previous research to measure an independent variable (IFRS) using earnings management (Nguyen, 2020; Barth et. al., 2008) in addition to trading volume (Timothy, 1994).

\subsection{Earnings management}

The bankruptcy of many international companies has drawn attention to the phenomenon of earnings management, which still lacks a scientific and practical basis for solving the problem. In this regard, questions have increased about the causes of scandals, collapses, and loss of investors' money in the global financial markets, since the crisis of the real world economy, the collapse of financial indicators and the closure of some banks have led to the collapse in confidence in the companies' executives and board members (Ashkar, 2010).

Earnings management can either reduce income in order to reduce taxes, or reduce income if it is high, or increase it if it is low; this is necessary to reduce sharp fluctuations in the level of profit to achieve stability of stock prices in the market.

This study has focused on the relationship between accruals management and earnings management practices; it also focuses on the cash flows to help them uncover a practice of earnings management, so it relies on the concept of accruals. Total accruals consist of optional and non-optional accruals, which are expressed as follows (Jones, 1991):

$$
T a_{i, t}=N D A_{i . t}+D A C_{i, t},
$$

where $T a_{i, t}$ - the total accruals of the company $i$ for year $t, N D A_{i . t}-$ no-optional accruals of the company $i$ for year $t$, and $D A C_{i, t}$ - optional accruals of the company $i$ for year $t$.
This study measured earnings management using the variability of change in net income scaled by total assets (Nguyen, 2020; Barth et al., 2008). When the variance is less, the change in net income is interpreted as evidence of earnings management. Also, the companies listed on the ASE may report higher profit after the application of IFRS than previously, thus, the change in net income scaled by total assets is used to measure earnings management in this study. Therefore, the following hypothesis is formulated as following:

$H_{i}$ : There is a relationship between the application of IFRS in terms of earnings management and the accounting information quality.

\subsection{Trading volume of stocks}

To measure trading volume of stocks, this study relied on Timothy (1994), which used the daily number of equity trades, the daily number of shares traded, and the daily total Jordanian dinar value of shares traded. Also, companies listed on the ASE can report higher trading volume after the application of IFRS than previously; therefore, the following hypothesis is put forward:

$\mathrm{H}_{2}$ : There is a relationship between the application of IFRS in terms of trading volume (DNET, DNST, and DTJDVST) and the accounting information quality.

\section{DATA}

Panel data were used to measure independent variables (earnings management and trading volume). The data were collected from 59 industrial companies listed on the Amman Stock Exchange between 2010 and 2018 based on the financial reports.

To measure the dependent variable (accounting information quality), questionnaires were used. After receiving 116 questionnaires valid for anal$y$ sis, the analysis units were board directors, managers, financial managers, and accountants. Based on this, the multiple regression was used to test hypotheses. Therefore, the regression equation for the study model is: 


$$
\begin{aligned}
& A I Q=\beta_{1} I N C O M E+\beta_{2} D N E T+ \\
& +\beta_{3} D N S T+\beta_{4} D T J D V S T+\varepsilon,
\end{aligned}
$$

where $Y=A I Q$ is the accounting information quality, $x_{1}=I N C O M E$ is net income scaled by total assets, $x_{2}=D N E T$ is the daily number of equity trades, $x_{3}=D N S T$ is the daily number of shares traded, $x_{4}=D T J D V S T$ is the daily total Jordanian dinar value of shares traded, and $\varepsilon-$ a standard error.

The regression coefficient $(\beta)$ indicates the influence of an independent variable (the application of IFRS in terms of earnings management and trading volume of stocks) on the dependent variable (accounting information quality). Since every single unit changes in the independent variable, $X$, the size of $\beta$ in the dependent variable $Y$ is expected to change (Hair et al., 2007).

\section{RESULTS}

Descriptive statistics

\begin{tabular}{|c|c|c|c|c|}
\hline Respondents & Frequency & Percent & $\begin{array}{c}\text { Valid } \\
\text { percent }\end{array}$ & $\begin{array}{c}\text { Cumulative } \\
\text { percent }\end{array}$ \\
\hline $\begin{array}{l}\text { Board } \\
\text { directors }\end{array}$ & 16 & 13.8 & 13.8 & 13.8 \\
\hline Managers & 26 & 22.4 & 22.4 & 36.2 \\
\hline $\begin{array}{l}\text { Financial } \\
\text { managers }\end{array}$ & 35 & 30.2 & 30.2 & 66.4 \\
\hline Accountants & 38 & 32.8 & 32.8 & 99.1 \\
\hline 44.00 & 1 & .9 & .9 & 100.0 \\
\hline Total & 116 & 100.0 & 100.0 & \\
\hline
\end{tabular}

Table 1. Questionnaire respondents

\section{DATA ANALYSIS AND HYPOTHESES TESTING}

\subsection{Data analysis}

To achieve the aims of the study, the multiple regression was used to test the study hypotheses. After collecting the final data (Hair et al., 2007), normality tests and variations in the sample responses were used (Homoscedasticity).

Thus, a normal distribution test was used, and a bell-shaped distribution curve was applied. The graph confirms that the normal distribution is free of homoscedasticity (see Figure 1).

Consequently, the Criterion Validity was used to test the result of the diagnosis of the relationship between the independent variables (Multicollinearity diagnostics); the Low correlation, less than $90 \%$, indicates that there is no Multicollinearity between the independent variables; this result is shown in Table 2.

To estimate an $R$ Square coefficient, a regression model summary was used (see Table 3 ).

\subsection{Model summary}

The regression model is 0.36 . This indicates that there is an amount of variance in the dependent variable (AIQ). Table 4 shows that, according to the ANOVA test, the regression model is statistically significant (0.000).

Dependent variable: AIQ

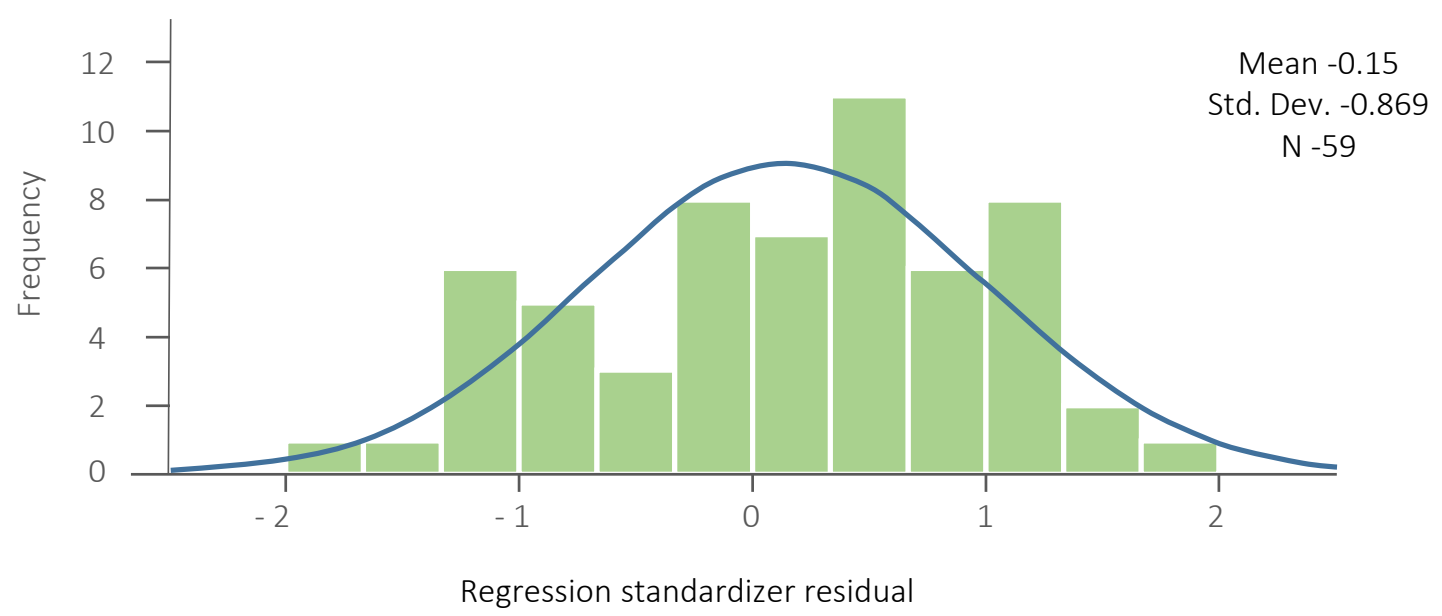

Figure 1. Regression standardized residual 
Table 2. Correlations

\begin{tabular}{|c|c|c|c|c|c|c|}
\hline \multirow{6}{*}{ Pearson correlation } & VARIABLES & AIQ & INCOME & DNET & DNST & DTJDVST \\
\hline & $\mathrm{AIQ}$ & 1.000 & .085 & .044 & .024 & .127 \\
\hline & INCOME & .085 & 1.000 & .073 & .050 & $-.096-$ \\
\hline & DNET & .044 & .073 & 1.000 & .080 & .202 \\
\hline & DNST & .024 & .050 & .080 & 1.000 & .220 \\
\hline & DTJDVST & .127 & $-.096-$ & .202 & .220 & 1.000 \\
\hline \multirow{5}{*}{ Sig. (1-tailed) } & $\mathrm{AlQ}$ & $\therefore$ & .261 & .370 & .428 & .169 \\
\hline & INCOME & .261 & . & .293 & .353 & .234 \\
\hline & DNET & .370 & .293 & & .000 & .062 \\
\hline & DNST & .428 & .353 & .000 & . & .047 \\
\hline & DTJDVST & .169 & .234 & .062 & .047 & . \\
\hline \multirow{5}{*}{$N$} & $\mathrm{AlQ}$ & 116 & 59 & 59 & 59 & 59 \\
\hline & INCOME & 59 & 59 & 59 & 59 & 59 \\
\hline & DNET & 59 & 59 & 59 & 59 & 59 \\
\hline & DNST & 59 & 59 & 59 & 59 & 59 \\
\hline & DTJDVST & 59 & 59 & 59 & 59 & 59 \\
\hline
\end{tabular}

Table 3. Model summary

\begin{tabular}{c|c|c|c|c}
\hline Model & $\mathbf{R}$ & $\boldsymbol{R}$ Square & Adjusted $\boldsymbol{R}$ Square & Std. Error of the Estimate \\
\hline 1 & $.590^{\mathrm{a}}$ & .360 & .350 & .29760 \\
\hline
\end{tabular}

Note: a. Predictors: (Constant), DTJDVST, INCOME, DNET, DNST, b. Dependent variable: AIQ.

Table 4. ANOVA ${ }^{b}$

\begin{tabular}{|c|c|c|c|c|c|c|}
\hline \multicolumn{2}{|c|}{ Model } & Sum of Squares & df & Mean Square & $\mathbf{F}$ & Sig. \\
\hline \multirow{3}{*}{1} & Regression & .180 & 4 & .045 & 2.507 & $.000^{2}$ \\
\hline & Residual & 4.783 & 54 & .089 & & \\
\hline & Total & 4.962 & 58 & & & \\
\hline
\end{tabular}

Note: a. Predictors: (Constant), DTJDVST, INCOME, DNET, DNST, b. Dependent variable: AIQ.

In this model (see Table 4), the relationship between the independent variables combined with each other and the dependent variable is positive and reaches $R=.59$.

\subsection{Multiple regression coefficient}

A multiple regression coefficient was used to show the relationship between the independent variables and the dependent variable as shown in Table 5.
Based on statistical analysis we note there is a statistically positive relationship between all of the (IVs) and (DV). As a result of that, the regression equation become as follows:

$$
Y=\beta_{1} \cdot 630+\beta_{2} \cdot 460+\beta_{3} \cdot 458 \beta_{4} \cdot 382+\varepsilon .
$$

\subsection{Hypotheses testing}

To test the hypotheses, this study relied on the Coefficients table (Table 5).

Table 5. Coefficients ${ }^{\mathrm{a}}$

\begin{tabular}{|c|c|c|c|c|c|c|}
\hline & \multirow{2}{*}{ Model } & \multicolumn{2}{|c|}{ Unstandardized coefficients } & \multirow{2}{*}{$\begin{array}{c}\text { Standardized coefficients } \\
\text { Beta }\end{array}$} & \multirow{2}{*}{$\mathbf{t}$} & \multirow{2}{*}{ Sig. } \\
\hline & & B & Std. error & & & \\
\hline \multirow{5}{*}{1} & (Constant) & 3.909 & .348 & & 81.642 & .000 \\
\hline & INCOME & .630 & .043 & .587 & 2.646 & .000 \\
\hline & DNET & .460 & .056 & .318 & 1.763 & .029 \\
\hline & DNST & .458 & .049 & .319 & 1.764 & .000 \\
\hline & DTJDVST & .382 & .042 & .445 & 2.049 & .000 \\
\hline
\end{tabular}

Note: a. Dependent variable: $A I Q$. 
H1: There is a relationship between the application of IFRS in terms of earnings management and the accounting information quality.

Based on Table 5, each unit increases in the independent variable (application of IFRS in terms of earnings management); it is expected to increase by 0.630 in the dependent variable (accounting information quality); furthermore, the direction of the relationship between earnings management (INCOME) and the accounting information quality is positive, as for the value of $T=2.646$, Alpha is less than .05. This indicates that the application of IFRS in terms of earnings management has a statistically significant impact on the dependent variable. Thus, the alternative hypothesis is accepted.

H2: There is a relationship between the application of IFRS in terms of trading volume (DNET, DNST, and DTJDVST) and the accounting information quality.

This hypothesis was divided into three sub-hypotheses according to the measurement of trading volume as follows:

H2a: There is a relationship between the application of IFRS in terms of the daily number of equity trades (DNET) and the accounting information quality.

According to Table 5, it was found that the dimension of DNET $=0.460$ is at a statistically significant level $=0.029$. This indicates that each unit increases in the independent variable (DNET), and it is expected to increase by 0.460 in the dependent variable (accounting information quality). The signal of the variable is positive, the $T$ test also indicates that the value of $T=1.763$. This means that the daily number of equity trades contributes to influencing the accounting information quality in manufacturing companies listed on the Amman Stock Exchange. Hence, the results of this test led to accepting the alternative hypothesis. The results also indicate that there is a statistically significant relationship between DNET and AIQ in manufacturing companies listed on the Amman Stock Exchange.

H2b: There is a relationship between the application of IFRS in terms of the daily number of shares traded (DNST) and the quality of accounting information.

Table 5 shows that the coefficient of DNST $=0.458$ is significant at the 0.05 level. For each unit change of the independent variable, the daily number of shares traded, there is an expected change of 0.458 in the dependent variable (accounting information quality). The sign is positive; in other words, for each increase of one unit in DNST, there is a 0.458 increase in AIQ. However, an examination of the $\mathrm{t}$-values $(t=1.764, p>0.05)$ indicates that DNST contributes to the improvement of AIQ. Therefore, the result has led to accepting the alternative hypothesis and rejecting the null hypothesis.

H2c: There is a relationship between the application of IFRS in terms of the daily total Jordanian dinar value of shares traded (DTJDVST) and the accounting information quality.

Referring to Table 5, the coefficient of the daily total Jordanian dinar value of shares traded $=.135$ is significant at the 0.000 level. For each unit change of the independent variable, DTJDVST, there is an expected change of .382 in the dependent variable; the accounting information quality. The sign is positive. In other words, for each increase of one unit in DTJDVST, one predicts a .382 increase in the accounting information quality. An examination of the $t$-values $(t=2.049, p<0.01)$ indicates that the daily total Jordanian dinar value of shares traded improves the quality of accounting information and therefore allows rejecting the null hypothesis.

\section{DISCUSSION}

The study has shown that the application of financial reporting standards has a positive relationship with the accounting information quality in terms of earnings management and trading volume, since the application of FIRS reduces earnings management. This result is in line with Nguyen (2020). In addition to that, the volume of stock trading is a very important factor underlying the decision to speculate in stocks. In fact, there are many researchers supporting the application of IFRS, because they believe that the ap- 
plication of these standards at the international level improves the quality of financial reports and statements and improves comparison features between companies at the local and international levels. In addition, it contributes to attracting foreign capital and achieving the best integration of capital markets. The researchers also found that the different accounting practices across countries create barriers between investors, foreigners and locals (Platikanova \& Perramon, 2012, Ozkan et al., 2012; McNichols \& Stubben, 2015; Marra \& Mazzola, 2014; Marra et al., 2011).

In contrast, the study of Lin and Chen (2005, pp. 79-103) in Chinese companies showed that the relevance of financial information resulting from the application of Chinese domestic accounting principles was better compared to information resulting from the application of IFRS. Callao and Lainez (2007, pp. 148-178) indicated that the implementation of IFRS in Spain improved comparison characteristics, but did not improve the appropriateness of financial reporting. Hassan et al. (2009, pp. 79-102), when studying the share holding companies listed on the Egyptian Stock Exchange during the period from 1995 to 2002, have found that the mandatory application of international accounting standards had a negative significant impact on company value, whereas, the voluntary application had a weak positive relationship with the value of a company. Hung and Subramanyam (2007) showed that 80 German industrial companies voluntarily adopted international accounting standards in the period from 1998 to 2002 and revealed the effect of applying these standards. When analyzing the differences between the financial reports prepared in accordance with GAAPs and the financial reports prepared in accordance with IAS, it was shown that the total assets and book value of shares were much greater according to IAS, and that the difference in the book value and net income was much higher compared to the reports prepared in accordance with the generally accepted accounting principles in German.

Furthermore, Bartov et al. (2005) conducted a study on a sample consisting of 417 German companies that implemented IAS/IFRS. They find out the quality of profitability compared to the companies that implemented the German domestic GAAP and the American GAAP. The researchers also showed that the quality of profitability was higher in companies that implemented IAS/IFRS and companies that implemented the American GAAPs, compared to companies that implemented the German domestic GAAP (Bartov et al., 2005). Ahmed et al. (2013) examined a sample of companies from 20 countries that obligated their companies to implement IFRS since 2005 to see whether if this measure improved the quality of reports in terms of reducing income-generating processes and overstating profit management. The study showed an increase in income-generating operations and earnings management after the mandatory application of IFRS. On the other hand, the result is in line with Barth et al. (2008) who found an increase in the value of net income and the book value of stocks after applying IFRS. In other country, the researchers investigated the impact of the adoption of IFRS in Nigerian companies on the value of earnings and showed that the adoption of IFRS had a higher earnings value.

Moreover, the finding of the study showed a statistically insignificant and negative effect between the cross product of book value and IFRS adoption (Odoemelam et al. 2019). Chandrapala Pathira Wasam (2011) measured the relationship between the volume of trading and returns of stocks on the Colombo Stock Exchange and showed a positive relationship between returns of stocks and contemporary changes in the volume of trading. Additionally, the study revealed a negative relationship between past trading volume and stock returns.

\section{CONCLUSION}

The study has shown that stocks are required and desirable in industrial companies listed on the Amman Stock Exchange, and since the amount of shares traded in the market is very large, the information derived from the volume of trading data will be of value, and since the average trading on shares on the Jordanian Stock Exchange is large, it achieves safety when applying various technical analysis founda- 
tions. It provides high liquidity in the sense that a stock trader in the Jordanian financial market has the ability to liquidate his shares at any moment, that is, to convert them into cash, because if the trading volume is low, the company cannot sell its shares at the time it wants. Also, the application of the standards of financial reports in companies listed on the ASE affects AIQ in terms of net income scaled by total assets, the daily number of equity trades, the daily number of shares traded, and the daily total Jordanian dinar value of shares traded.

The application of financial reporting standards in Jordan has led to the possibility of converting stocks into cash quickly, at the lowest cost and at a price close to the last trading price. The higher the trading rates on the stock, the higher its liquidity; this gives investors the ability to enter and exit this stock whenever they want. Consequently, the risk factor has been reduced to invest in stocks, where liquidity provides wider opportunities for buying and selling, it increases the investment attractiveness of the stock or the Jordanian market, and the liquidity works to regularize prices or stabilize them in the market, since it leads to a decrease in sharp fluctuations in price, and then low volatility in it. This is sometimes called the depth of the market. Finally, the application of IFRS has a positive impact on the improvement of AIQ in industrial companies listed on the ASE.

Therefore, this study recommends highlighting transparency in financial statements, as most experimental evidence indicates that transparency in the financial statements is beneficial to capital market participants to improve the efficiency of the Jordanian financial market. In an attempt to develop the (AIQ), this study is based on the responses of the board directors, managers, financial managers, accountants, and financial reports as regards assessing the effectiveness of IFRS on AIQ. Hence, it is believed that future research should obtaining valuable information from external Auditors. Research employing External Auditors as evaluators of application of IFRS effectiveness and their impact on AIQ will be crucial in confirming the results of the current study.

\section{AUTHOR CONTRIBUTIONS}

Conceptualization: Qasim Ahmad Alawaqleh.

Data curation: Qasim Ahmad Alawaqleh.

Formal analysis: Qasim Ahmad Alawaqleh.

Investigation: Qasim Ahmad Alawaqleh.

Methodology: Qasim Ahmad Alawaqleh.

Project administration: Qasim Ahmad Alawaqleh.

Validation: Qasim Ahmad Alawaqleh.

Writing - original draft: Qasim Ahmad Alawaqleh.

Writing - review \& editing: Qasim Ahmad Alawaqleh.

\section{REFERENCES}

1. Ahmed, K., Chalmers, K., \& Khlif, H. (2013). A Meta-analysis of IFRS adoption effects. The International Journal of Accounting, 48(2), 173-217. https://doi. org/10.1016/j.intacc.2013.04.002

2. Barth, M. E., Landsman, W. R., \& Lang, M. (2008). International Accounting Standards and Accounting Quality. Journal of Accounting Research, 46(3), 467-498. https://doi.org/10.1111/j.1475679X.2008.00287.x
3. Barth, M., Landsman, W., \& Lang, M. (2005). International accounting standars and accounting quality (Stanford University Graduate School of Business Research Paper No. 1976). Retrieved from http:// ssrn.com/abstract $=688041$

4. Bartov, E., Goldberg, S., \& Kim, M. (2005). Comparative Value Relevance Among German, U.S., and International Accounting Standards: A German Stock Market
Perspective. Journal of Accounting, Auditing and Finance, 20, 95-119. https://doi.org/10.1177\%2F014855 8X0502000201

5. Beest, F., Braam, G., \& Boelens, S. (2009). Quality of Financial Reporting: Measuring qualitative characteristics. NICE. Retrieved from https://www.researchgate. net/publication/254877109_Quality_of_financial_reporting_measuring_qualitative_characteristics 
6. Callao, S., Jarne, J. I., \& Lainez, J. A. (2007). Adoption of IFRS in Spain: Effect on the comparability and relevance of financial reporting. Journal of International Accounting, Auditing and Taxation, 16, 148-178. https:// doi.org/10.1016/j.intaccaudtax.2007.06.002

7. ChandraPala Pathira Wasam. (2011). The Relationship Between Trading Volume and Stock Returns. Journal of Competitiveness, 3. Retrieved from https://www. cjournal.cz/files/65.pdf

8. Cheung, E., Evans, E., \& Wright, S. (2010). An historical review of quality in financial reporting in Australia. Pacific Accounting Review, 22(2), 147-169. Retrieved from https://www.researchgate. net/publication/235285049_An_ historical_review_of_quality_in_ financial_reporting_in_Australia

9. David J. Cooper. (2013). Accounting and Globalization. Seventh Asia Pacific Interdisciplinary Research in Accounting Conference. Kobe, July 26-28, 2013.

10. Goodwin \& Heaney. (2008). The Effects of International Financial Reporting Standards on the Accounts and Accounting Quality of Australian Firms: A Retrospective Study. Journal of Contemporary Accounting \& Economics, 4(2), 89-119. https://doi.org/10.1016/ S1815-5669(10)70031-X

11. Graham, R., King, R., \& Bailes, J. (2000). The value relevance of accounting information during a financial crisis: Thailand and the 1997 decline in the value of the baht. Journal of International Financial Management \& Accounting, 11(2), 84-107. https://doi. org/10.1111/1467-646X.00057

12. Hail, L., Leuz, C., \& Wysocki, P. (2010). Global accounting convergence and the potential adoption of IFRS by the U.S. (Part I): Conceptual Underpinnings and Economics Analysis. Accounting Horizons, 24(3), 355-394. Retrieved from https://papers.ssrn. $\mathrm{com} /$ sol3/papers.cfm?abstract_ $\mathrm{id}=1674723$

13. Hair, J. E., Anderson, R. E., Tatham, R. L., Black, W. C., \& Babin,
B. J. (2006). Multivariate Data Analysis. USA: Pearson Prentice Hall International Inc.

14. Hassan, O. A. G., Romilly, P., Giorgioni, G., \& Power. D. (2009). The value relevance of disclosure: Evidence from the emerging capital market of Egypt. The International of Accounting, 44(1), 79-102. https://doi.org/10.1016/j. intacc.2008.12.005

15. Hellstrom, K. (2006). The value relevance of financial accounting information in a transition economy: The case of the Czech Republic. European Accounting Review, 15(3), 325-349. https://doi. org/10.1080/09638180600916242

16. Hsu, A. W.-H., \& Pourjalali, H. (2014). The Impact of IAS No. 27 on the Market's Ability to Anticipate Future Earnings. Contemporary Accounting Research. Forthcoming. Retrieved from https://www.researchgate.net/ publication/261223177_The_Impact_of_IAS_No_27_on_the _ Market's_Ability_to_Anticipate_ Future_Earnings

17. Hung, M., \& K. R. Subramanyam. (2007). Financial statement effects of adopting international accounting standards: the case of Germany. Review of Accounting Studies, 12, 623-657. Retrieved from https://www.researchgate.net/ publication/225145713_Financial_ Statement_Effects_of_Adopting_ International_Accounting_Standards_The_Case_of_Germany

18. Huoshu Peng, \& Mei-Hui Chen. (2014). A Comparison of the Value Relevance of IFRS with Taiwanese GAAP Accounting Information. Retrieved from https://af.polyu. edu.hk/media/7237/518_final.pdf

19. Kothari, S. (2000). The role of financial reporting in reducing financial risks in the market. Federal Reserve Bank of Boston. Conference Series, (June), 89-112. Retrieved from https:// www.researchgate.net/publication/5027140_The_role_of_financial_reporting_in_reducing_financial_risks_in_the_market

20. Levitt, A. (1998). The Importance of High Quality Accounting Standards. Accounting Horizons,
12(2), 79-82. Retrieved from https://www.econbiz.de/Record/ the-importance-of-high-qualityaccounting-standards-levitt-arthur/10007064835

21. Lin, Z. J., \& Chen, F. (2005). Value relevance of international accounting standards harmonization: Evidence from A-share and B-share markets in China. Journal of International Accounting, Auditing and Taxation, 14(2), 79-103. https://doi.org/10.1016/j.intaccaudtax.2005.08.001

22. Lopes, A. (2002). The value relevance of Brazilian accounting numbers: An empirical investigation (Working Paper no. 1). University of Sao Paulo, Department of Accounting. Retrieved from http://ssrn.com/abstract=311459

23. Louis, H., \& Urcan, O. (2014). The effect of IFRS on cross-border acquisitions (Working Paper July, 2014). Retrieved from http://ssrn. com/abstract $=2164995$

24. Marra, A., \& Mazzola, P. (2014). Is corporate board more effective under IFRS or "It's just an illusion"? Journal of Accounting, Auditing \& Finance, 29, 31-60. https://doi.org /10.1177\%2F0148558X13512405

25. Marra, A., Mazzola, P., \& Prencipe, A. (2011). Board monitoring and earnings management pre- and post-IFRS. The International Journal of Accounting, 46, 205230. Retrieved from https:// www.researchgate.net/publication/227411121_Board_Monitoring_and_Earnings_Management_ Pre-_and_Post-IFRS

26. McNichols, F., \& Stubben, S., (2015). The effect of target-firm accounting quality on valuations in acquisitions. Review of Accounting Studies, 20, 110-140. Retrieved from https://www.gsb. stanford.edu/faculty-research/ publications/effect-target-firmaccounting-quality-valuationacquisitions

27. Naomi S. Soderstrom \& Kevin Jialin Sun, (2007). IFRS Adoption and Accounting Quality: A Review. European Accounting Review, Forthcoming. Retrieved from http://ssrn.com/abstract $=1008416$ 
28. Nguen, V. H. (2020). The Impact of IAS on the Accounting Quality of Vietnamese Enterprises. International Journal of Innovation, Creativity and Change, 13(11), 419-432. Retrieved from https:// www.ijicc.net/images/vol_13/ Iss_11/131130_Hoa_2020_E_R. pdf

29. Odoemelam, N., Okafor, R. G., \& Ofoegbu, N. G. (2019). Effect of international financial reporting standard (IFRS) adoption on earnings value relevance of quoted Nigerian firms. Cogent Business \& Management, 6, 1643520. https:// doi.org/10.1080/23311975.2019.1 643520

30. Ozkan, N., Singer, Z., \& You, H. (2012). Mandatory IFRS adoption and the contractual usefulness of accounting information in executive compensation. Journal of Accounting Research, 50(4),

1077-1107. https://doi.org/10.1111/ j.1475-679X.2012.00453.X

31. Platikanova, P., \& Perramon, J. (2012). Economic consequences of the first-time IFRS adoption in Europe. Spanish Journal of Finance and Accounting, 41, 497-519.

Retrieved from https://www.aeca. es/old/refc_1972-2013/2012/156-2. pdf

32. Pope, P. F., \& McLeay, S. J. (2011). The European IFRS experiment: objectives, research challenges and some early evidence. Journal Accounting and Business Research, 41(3), 233-266. https://doi.org/10.1 080/00014788.2011.575002

33. Ramanna, K., \& Sletten, W. (2014). Network Effects in Countries' Adoption of IFRS. The Accounting Review, 89(4), 1517-1543. https:// doi.org/10.2308/accr-50717
34. Richards, A. (1996). Volatility and predictability in national stock markets: How doemerging and mature markets differ? International Monetary Fund, 43(3), 461. Retrieved from https://www. imf.org/en/Publications/WP/ Issues/2016/12/30/Volatility-andPredictability-in-National-StockMarkets-How-Do-Emerging-andMature-Markets-2015

35. Stojilkovic, M. (2011). Towards a criticism of fair value accounting. Economics and Organization, 8(1), 91-109. Retrieved from http://facta.junis.ni.ac.rs/eao/eao201101/ eao201101-08.pdf

36. Timothy J. Brailsford (1994). The Empirical Relationship between Trading Volume, Returns and Volatility (Research Paper 94-01. December 1994). 